\title{
AN EMPIRICAL STUDY OF TOP MANAGEMENT ENGAGEMENT IN TOTAL QUALITY MANAGEMENT: A CASE OF PAKISTAN'S CONSTRUCTION INDUSTRY
}

\author{
Muhammad Irfan ${ }^{1}$, Shafi Ullah ${ }^{1}$, Maha Nadeem ${ }^{2}$
}

\begin{abstract}
${ }^{1}$ Department of Civil Engineering, University of Lahore (Islamabad Campus), Pakistan

${ }^{2}$ Department of Construction Engineering and Management, National University of Sciences and Technology, Islamabad, Pakistan
\end{abstract}

Received: 4 April 2020

Revised: 26 May 2020 Accepted: 8 August 2020

\begin{abstract}
Top management obligation towards quality management is seen as one of the key factors in deciding its success. The local construction industry of Pakistan is far away from construction quality principles. In connection to this, the current study attempts to indicate the significance of quality management of Pakistani construction industry from the perspective of top management engagement. The constructs were extracted from published literature based on top management engagement and investigated the top management's engagement towards quality administration in the construction industry. Survey questionnaires were distributed among senior management from the construction organizations registered with Pakistan Engineering Counsel. From the results, it is demonstrated that top management is willing to adopt most of the constructs however, it is astonishing that the interest to incorporate quality management in cost and time perspectives is still lacking. Hence, the areas of quality are still a secondary consideration for most of the top management. Therefore, it is the need of hour that this attitude must be expanded to a more agreeable level.
\end{abstract}

Keywords: Quality, quality management, top management, construction industry.

\section{INTRODUCTION}

The usual worries of the clients in the construction industry consist of whether the project can be finished inside the allocated time and cost and the desired quality of the project is achieved or not. Ashford (2002) states quality as the sum of factors which make the product acceptable. The basic idea of quality can be shaped into various quality factors which contain reliability, perceived quality, conformance, serviceability, performance and durability. The definition of quality is not consistent, rather it varies from person to person defining it in their own perspective: it is viewed by some as a mere conformance to the specification required. Some view it as a value paid for the price or in other words performance to standards (Barrett, 2000). And according to Rosenfeld (2009), quality for the construction firms means fulfilling the requirements of the clients in specified time and budget.

Quality of work, as far as construction industry is concerned, can be evaluated or determined using the aforementioned quality factors. As a result, the outcome may well be subjective taking into consideration few factors namely perceived quality and aesthetics. Keeping in mind these factors, contractor should implement these quality dimensions at good levels for better quality. Regarding the importance of quality management, Harris and McCaffer (2001) highlighted that for the organizations i.e. the construction 
organizations, to compete proficiently; quality management is of utmost significance. Quality of the works executed or performed by the certain organization speaks volume for itself and has a great importance in the construction industry may it be in the form of reputation or the competitive edge over the rival organizations. Similarly, quality management can play a vital role in deciding the edge that an organization gets when being in competitiveness with other organizations, states Abdul-Rahman (1996), where as in the same spectrum Landin (2000) explained quality management as a mean of enhancing organization's effectiveness and promoting competitive advantage.

Top management engagement is most significant factor that shows the measures taken in the construction as far as total quality management (TQM) performance is concerned (Pheng, \& Teo, 2004). Also, for the successful implementation of the ISO 9000, top management commitment is a very crucial factor as concluded by Chin, Tummala and Chan (2003). Moreover, top management's engagement is very important not just in the planning or initiation phase but in each and every building phase to ensure quality implementation (Arditi, \& Gunaydin, 1997). Similarly, Biggar (1990) emphasized that the top management should invest time in it and instead of ignoring they must support and implement the TQM process. The implementation of the ISO 9001:2000 has few requirements or actions that need to be taken as an organization in relation with management commitment and they are: transferring the importance of customer satisfaction along with the due alliance with by-laws and other regulatory requisites, clear cut policy as far as quality is concerned, esurience of basic quality objectives formation, input of management in the form of reviews etc. and lastly to guarantee resources.

The above-mentioned literature is used while examining the idea of quality coupled with its management in the construction industry. It is addressed that top management has a vital role to play in quality management. Engagement from the top hierarchy in the organizational structure is always very critical and is considered to be the significant factor towards the success determination. The situation of
Pakistan's construction industry is not much different from other developed countries when it comes to the management of quality in the processes involved in the construction. For the matter of fact, it is actually worse as compared to other countries (Asim, uz Zaman, \& Zarif, 2013; Memon, Khatri, \& Memon, 2013). Thus, this situation demands a change in the approaches so that the improvement can be made in the present state of the construction industry. So, as a result of this, the research has been carried out to look at quality management in Pakistan's construction industry from the engagement of top management's perspective. Because very limited amount of literature is present that is based on domestic cases so it is very difficult to perfectly analyze the understanding of the top management towards top management engagement. Through this study, following objectives were considered during our studies: to determine the engagement constructs from publications and to evaluate the top administration obligation (client, consultant and contractors' preferences) towards quality administration in construction projects of building and Roads in Pakistan's construction sector. The results obtained will be a source of guidance for all decision makers and top management in implementing quality management in the construction industry of Pakistan.

\section{LITERATURE REVIEW}

Commitment or Obligation is the state or quality of being devoted to a reason or activity (Oxford Dictionary, 2001). To determine the constructs for top management engagement for quality management, few researches have been reviewed. Researchers like Ahire and O'shaughnessy (1998); Chin et al. (2003); Pheng and Teo (2004), have drawn much attention on top management engagement in quality management implementation. Rodgers, Hunter and Rogers (1993) mentioned the effect of top management obligations on the accomplishment of management program in general.

\section{Top Management engagements}

Management role in quality management has been highlighted as the crucial requirement for a successful quality improvement implementation. Consistent with Pheng and 
Teo (2004), the degree of support that management takes within the implementation, a complete quality environment is extremely critical to the success of Total Quality Management (TQM) implementation and TQM cannot be fully implemented if there is a lack of commitment from top management. Commitment of top managers in TQM implementation will enable the workers to follow their direction and way of working.

Total Quality Management (TQM) may be a management approach which aimed toward incorporating awareness of quality altogether organizational processes (Savolainen, 2000). Many organizations are striving for quality products and services which will meet or exceed customer's expectations and as a result of this they are checking out approaches to managing people and production systems which will assure the transformation of inputs into quality output (Ugboro, \& Obeng, 2000). Much research has been through with regards to the implementation of total quality management. Pheng and Teo (2004) acknowledged that with the adoption of TQM there are benefits for higher customer satisfaction, better quality products and better market shares. Customer satisfaction is one among the prime objectives of TQM and it is foremost widely discussed approach to directing organizational efforts towards the goal of customer satisfaction consistent with Ugboro and Obeng (2000). TQM theory is predicated on; continuous improvement, top management leadership and engagement to the goal of customer satisfaction, employee empowerment and customer focus.

Top management stands because the winner of any institution, organization, company, in which the result may be a reflection of their capability and commitment. TQM can't be fully implemented without total commitment from top managers. Garcia-Bernal and GarciaCasarejos (2020) points out that some TQM programs have failed within the implementation and thanks to the negligence and reluctance of top management to delegate power and responsibility to subordinates. Some managers are afraid due to insecurity because they believe they are in charge of their subordinates. Some do believe that the subordinates lack the managerial ability and appropriate skills and as a result of this there is that lack of confidence to delegate task. That is the reason why in TQM implementation training may be a vital imperative (Elghamrawy, \& Shibayama, 2008). Top management should be responsible for training the workers to realize the talents and skill required to perform their task effectively. Top managers got to realize that empowering employees through self-managed teams; quality improvement teams and management teams will bring much benefit to the organization through individual knowledge and skills (Kuo, \& Kuo, 2010). Thus, top management engagement requires that management in the least levels should reassign the role from authoritarian to coaching facilitator because top management commitment doesn't mean dictatorship but rather their ability to watch and control their empowered employees and giving room for their middle and line managers to require responsibility in deciding (Sullivan, 2011).

Understanding the active contribution and support as the constructs for management obligation was a concept founded by Biggar (1990). Goal setting, feedback, and participation being the roles to be played by the management was the opinion in Rodgers et al. (1993). Low and Omar (1997) explained that the level of commitment is shown by management in quality management. Crosby (1984) emphasized that the contribution and the positive approach reflect the commitment of administration in quality management. Goffin and Szwejczewski (1996) on the same matter figured the builds of time and effort spent, proficiency, clear areas, and emphasis on employees. Arditi and Gunaydin (1997) were more focused in setting quality administration as the primacy, and to lead in its application. Similarly, Goetsch (1997) emphasized on the contribution, and resources distribution. Ahire and O'shaughnessy (1998) pointed that participation, featured priority, goals, and resources allocation can play significant role in implying quality management practices. Chan and Tam (2000) were also among investigators who highlighted primacy and resources distribution as the builds of management obligation. On this particular issue, Harris and McCaffer (2001) put more emphasis on initiative whereas on the other hand Russel and Taylor (2006) were analyzing the involvement related factors. 
Haupt and Whiteman (2004) reviewed support and initiatives as the constructs for management commitment. Whereas, Pheng and Teo (2004) put their emphases on budget distribution, scheduling for change and providing a few means of process monitoring. Thevnin (2004) gave change for quality development willingness, and it showed contribution to quantify organization's commitment whereas, on the same issue
Dadzie (2004) emphasized on resource distribution, initiatives, collaboration and rewards. Based on the literature review the obligation towards quality administration is summed up into nine constructs. These are: quality goals, priority, efforts, involvement, and resource distribution, attitude to change, empowerment, leadership and trainings. The summary of these constructs along with their references are presented in Table 1.

Table 1: Top management engagement constructs

\begin{tabular}{|l|l|}
\hline \multicolumn{1}{|c|}{ Top Management Engagement Constructs } & \multicolumn{1}{c|}{ Author References } \\
\hline Priority, resources allocation & Chan, Chu, \& Yuen (2000) \\
\hline $\begin{array}{l}\text { Common goal, review and continuous } \\
\text { improvement, involvement and leadership, attitude to } \\
\text { change }\end{array}$ & Chin \& Choi (2003) \\
\hline Leadership & Jaafari (2000), Cho (2017) \\
\hline Willing to change, participation & Thevnin (2004) \\
\hline $\begin{array}{l}\text { Initiatives, resources allocation, communication, } \\
\text { recognition/reward }\end{array}$ & Dadzie (2004) \\
\hline Initiative & Haupt \& Whiteman (2004) \\
\hline Involvement and trainings & Taylor \& Wright (2003) \\
\hline $\begin{array}{l}\text { Allocation of budget, planning for change, } \\
\text { providing methods of monitoring progress }\end{array}$ & Pheng \& Teo (2004) \\
\hline Initiatives, support and empowerment & $\begin{array}{l}\text { Harris \& McCaffer (2001); } \\
\text { Greasley, Bryman, Dainty, } \\
\text { Price, Soetanto \& King (2005) }\end{array}$ \\
\hline
\end{tabular}

\section{METHODOLOGY}

The survey questionnaire that incorporated questions was designed to determine the top management engagement towards the implementation of quality management in the construction projects from various constructs extracted after detailed literature review. This research applies the practice of questionnaire survey to discern the top management obligation towards the enactment of quality management in the construction projects from the 9 formulates mentioned in Table 1 .
Survey questionnaires were circulated by hand and through email to the General Managers, Project Directors, Project Coordinators \& Deputy Directors working at various construction projects. Respondents were approached professionally. Total number of questionnaires circulated for this study were 100. The population for this research is divided into two main strata i.e. building construction projects and road construction projects. Each main stratum was further divided into three sub strata i.e. clients, consultants and contractors as shown in Figure 1. 


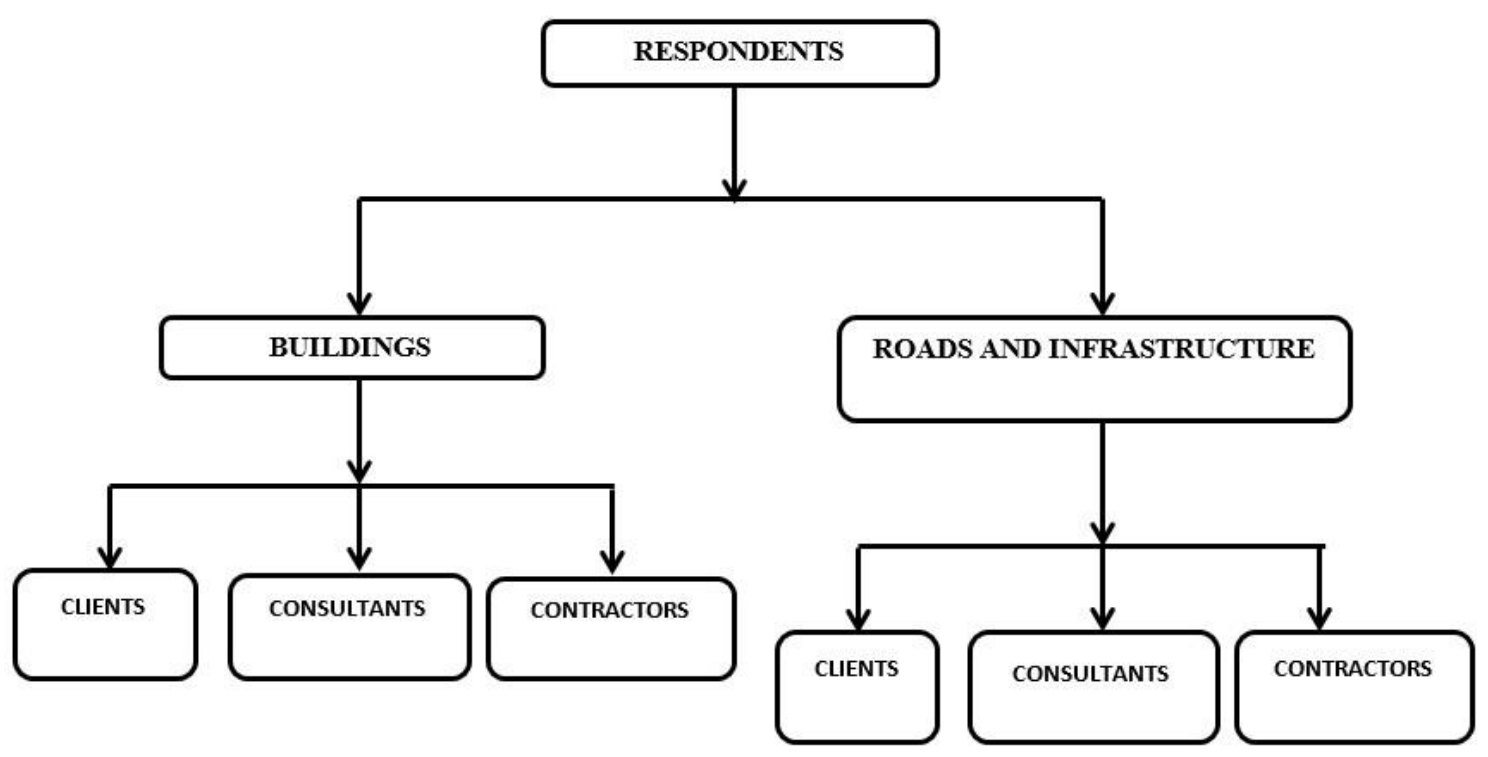

Figure 1: Classification of Respondents

The reason for dividing into these groups was to show the preferences of clients, consultants and contractors concerning top management engagement on quality management enactment. Contractors of higher categories $\mathrm{C} 1$ and above listed with Pakistan Engineering Counsel were nominated as they perform a key role in the construction industry and their enactment of quality management imitates the actual situation.

\subsection{Response rate}

Out of 100 questionnaires, 63 responses were received and acknowledged. Out of these 63 responses, 3 questionnaires that were sent through email, few of the questions were left blank and therefore, they were rejected. So, the total number of accurate responses used for analysis are 60 in number. The response rate for this survey was $60 \%$.

These 60 respondents included 33 respondents from road construction projects and 27 respondents from building construction projects. The 33 respondents from road construction project included 17 responses from client organizations, 8 respondents from Consultant organizations and 8 respondents from contractor organizations. Similarly, 27 respondents from building projects included 10 respondents from client, 9 respondents from consultant and 8 respondents from contractor organizations as shown in Table 2. Numbers of responses were enough for the analysis and statistical tests.

Table 2: Respondent's Stats

\begin{tabular}{|l|c|c|c|}
\hline \multicolumn{1}{|c|}{ Respondents } & Client & Consultant & Contractor \\
\hline Building Projects & 10 & 9 & 8 \\
\hline Road construction Projects & 17 & 8 & 8 \\
\hline Total & 27 & 17 & 16 \\
\hline \multicolumn{1}{|c|}{ Over all total } & \multicolumn{3}{|c|}{60} \\
\hline
\end{tabular}

\subsection{Validity and reliability}

Measuring the internal consistency and reliability of data, the value of Cronbach's alpha was 0.83 . Values ranging from $0.70-0.95$ are acceptable for further analysis (Tavakol, \& Dennick, 2011). Therefore, the data used for present study are valid and reliable for further analysis (Irfan, Malik, \& Kaka Khel, 2020).

\section{RESULTS AND DISCUSSIONS:}

Each respondent was required to answer the questions according to the level of his/her covenant that the top management of his/her organization is accomplishing. The questions were based on the Likert scale $(1=$ Strongly Disagree, $2=$ Disagree, $3=$ Neutral, $4=$ Agree, 5 =Strongly Agree) . 


\section{i. Goals for Quality:}

Questions on the idea of quality goals comprised of Questions No. $1 \& 2$.

In Question No. 1 overall respondents who "agreed" were $43.33 \%$ and who "strongly agreed" were $50 \%$. So, the overall percentage of respondents who "agreed" and "strongly agreed" to this question is $93.33 \%$. In Question No.2 overall respondents who "agreed" were $36.66 \%$ and who "strongly agreed" were $45 \%$. So, the total percentage of respondents who "agreed" and "strongly agreed" to this question is $81.66 \%$. The overall result containing the clients, consultants and contractors for questions No. 1 and No. 2 is shown in Table 3 which illustrates that top management of construction corporations have goals for their projects.

\section{ii. Priority:}

Questions on the build of priority contained Questions No. $3 \& 4$.

In Question No. 3 total respondents who "agreed" were $31.66 \%$ and who" strongly agreed" were $6.66 \%$. So, the total percentage of respondents who "agreed" and "strongly agreed" to this question is $38.32 \%$. In Question No.4 total respondents who agreed were 23.33 $\%$ and who "strongly agreed "were $5 \%$. So, the total percentage of respondents who "agreed" and "strongly agreed" to this question is $23.33 \%$. The overall outcome including the clients, consultants and contractors for questions No. 3 and No. 4 which is called Priority can be shown in Table 3 . From the result, it is noticeably shown that top management of construction organization is not giving quality significance with respect to cost and time.

\section{iii. Efforts:}

Questions on the build of efforts comprised of Questions No. 5 \& 6 .

In Question No. 5 total respondents who agreed were $51.66 \%$ and who strongly agreed were $35 \%$. So, the overall percentage of respondents who "agreed" and "strongly agreed" to this question is $86.66 \%$. In Question No. 6 overall respondents who agreed were $48.33 \%$ and who strongly agreed were $28.33 \%$. So, the overall percentage of respondents who "agreed" and "strongly agreed" to this question is $76.66 \%$. The complete result including the clients, consultants and contractors for questions No. 5 and No. 6 is shown in Table 3. The results show that top management of construction corporations is placing their efforts in implementation of quality management for their construction projects.

\section{iv. Involvement:}

Questions on formulate of involvement comprised of Questions No. 7 \& 8.

In Question No. 7 overall respondents who "agreed" were $58.33 \%$ and who "strongly agreed" were $15 \%$. So, the total percentage of respondents who "agreed "and "strongly agreed" to this question is $73.3 \%$. In Question No. 8 overall respondents who "agreed" were $40 \%$ and who "strongly agreed" were $25 \%$. Hence, the total percentage of respondents who "agreed" and "strongly agreed" to this question is $65 \%$. The overall end result encompassing the clients, consultants and contractors for questions No. 7 and No. 8 which is called Involvement is shown in Table 3. The results illustrate that top administration of construction corporations needs to get more involved in the process of quality management.

\section{v. Changing of Attitude:}

Questions on the conception of changing of Attitude comprised of Questions No. 9 \& 10.

In Question No. 9 overall respondents who "agreed" were $36.33 \%$ and who "strongly agreed" were $35 \%$. So, the total percentage of respondents who "agreed" and "strongly agreed" to this question is $71.33 \%$. In Question No. 10 overall respondents who "agreed" were $56.66 \%$ and who "strongly agreed" were $35 \%$.

So, the total percentage of respondents who "agreed" and "strongly agreed" to this question is $91.66 \%$. The overall end result for questions No. 9 and No. 10 is shown in Table 3. The results reveal that top management is having optimistic approach towards changes for having quality management implementation. 


\section{vi. Allocation of Resources:}

Questions on the notion of Resources Allocation contained Questions No. $11 \& 12$.

In Question No. 11 overall respondents who "agreed" were $41.6 \%$ and who "strongly agreed" were $10 \%$. So, the total percentage of respondents who "agreed" and "strongly agreed" to this question is $51.6 \%$. In Question No. 12 overall respondents who "agreed" were $33.33 \%$ and who "strongly agreed" were $10 \%$. So, the total percentage of respondents who "agreed" and "strongly agreed" to this question is $43.33 \%$. The overall result counting the clients, consultants and contractors for questions No. 11 and No. 12 is shown in Table 3.

Table 3: Responses against all formulates

\begin{tabular}{|l|c|c|c|}
\hline \multicolumn{1}{|c|}{ Formulate } & Client & Consultant & Contractor \\
\hline Goals of quality & $91.75 \%$ & $82.96 \%$ & $90.63 \%$ \\
\hline Priority & $35.60 \%$ & $40.25 \%$ & $34.37 \%$ \\
\hline Effort & $75.29 \%$ & $88.88 \%$ & $87.50 \%$ \\
\hline Involvement & $68.29 \%$ & $72.50 \%$ & $65.63 \%$ \\
\hline Changing of attitude & $78.81 \%$ & $88.19 \%$ & $81.25 \%$ \\
\hline \multirow{2}{*}{ Resource allocation } & $44.99 \%$ & $60.06 \%$ & $37.50 \%$ \\
\hline Empowerment formulate & $76.15 \%$ & $82.64 \%$ & $93.75 \%$ \\
\hline Leadership & $94.12 \%$ & $100 \%$ & $93.75 \%$ \\
\hline Training of employees & $84.12 \%$ & $76.39 \%$ & $87.50 \%$ \\
\hline
\end{tabular}

\section{vii. Empowerment of Employees:}

Questions on the perception of Empowerment comprised of Question No. 13. In Question No. 13 overall respondents who "agreed" were 45 $\%$ and who "strongly agreed" were $38.33 \%$. So, the total percentage of respondents who "agreed" and "strongly agreed" to this question is $83.33 \%$. The overall result including the clients, consultants and contractors for question No. 13 is shown in Table 3.

\section{viii. Leadership:}

Questions on the formulate of leadership included Question No. 14. In Question No. 14 overall respondents who "agreed" were 43.33 $\%$ and who "strongly agreed" were $51.66 \%$.
So, the total percentage of respondents who "agreed" and "strongly agreed" to this question is $94.99 \%$. The overall result including clients, consultants and contractors for question No. 14 is shown in Table 3.

\section{ix. Training of Employees:}

Questions on the conception of training covered Question No. 15. In Question No. 15 overall respondents who "agreed" were 41.66 $\%$ and who "strongly agreed" were $51.66 \%$. So, the total percentage of respondents who "agreed" and "strongly agreed" to this question is $93.32 \%$. The end result containing the clients, consultants and contractors for question No. 15 is shown in Table 3. 
Table 4: Respondents from building projects

\begin{tabular}{|c|c|c|c|c|c|c|}
\hline \multicolumn{7}{|c|}{ BUILDINGS PROJECTS } \\
\hline $\begin{array}{l}\dot{z} \\
\dot{n}\end{array}$ & 吾 & 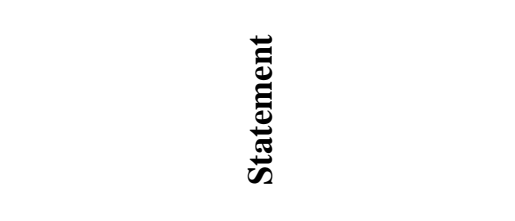 & 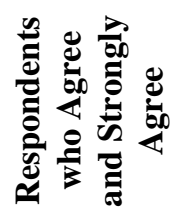 & 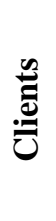 & 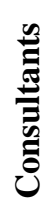 & ن \\
\hline 1 & \multirow{2}{*}{$\begin{array}{l}\text { "Goals for } \\
\text { Quality" }\end{array}$} & $\begin{array}{l}\text { Pinpoint goals of quality for } \\
\text { project management to accomplish }\end{array}$ & $92.59 \%$ & $\stackrel{\circ}{8}$ & $\frac{\sqrt{2}}{\stackrel{2}{2}}$ & $\stackrel{8}{8}$ \\
\hline 2 & & $\begin{array}{l}\text { Guarantee that quality goals of } \\
\text { project are known to every } \\
\text { participant of project management } \\
\text { team }\end{array}$ & $85.18 \%$ & $\stackrel{8}{8}$ & $\begin{array}{l}\stackrel{0}{8} \\
\dot{6} \\
\dot{8}\end{array}$ & $\underset{\substack{\infty \\
\infty}}{\substack{\infty \\
\infty}}$ \\
\hline 3 & \multirow{2}{*}{ "Priority" } & $\begin{array}{l}\text { Consider quality as being more } \\
\text { imperative than cost }\end{array}$ & $40.74 \%$ & $\begin{array}{l}\delta^{0} \\
i n\end{array}$ & 官 & $\stackrel{8}{i}$ \\
\hline 4 & & $\begin{array}{l}\text { Consider quality as being more } \\
\text { imperative than time }\end{array}$ & $25.92 \%$ & \&̊ & $\stackrel{\circ}{=}$ & $\stackrel{8}{\circ}$ \\
\hline 5 & \multirow{2}{*}{ "Efforts" } & $\begin{array}{l}\text { Make sure that constant efforts are } \\
\text { made in enhancing the quality of } \\
\text { construction works }\end{array}$ & $85.18 \%$ & ஓ̊ & $\stackrel{\circ}{\stackrel{2}{\gtrless}}$ & $\underset{\substack{\infty \\
\infty}}{\infty}$ \\
\hline 6 & & $\begin{array}{c}\text { Continuously source for new } \\
\text { concepts to improve construction } \\
\text { work quality }\end{array}$ & $81.48 \%$ & @̊ & 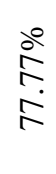 & $\stackrel{8}{8}$ \\
\hline 7 & \multirow{2}{*}{ "Involvement" } & $\begin{array}{l}\text { Implicate regularly in the quality } \\
\text { management process }\end{array}$ & $81.48 \%$ & 迥 & $\check{8}_{0}^{\circ}$ & \begin{tabular}{l}
8 \\
\multirow{2}{n}{} \\
î
\end{tabular} \\
\hline 8 & & $\begin{array}{l}\text { Personally involved in the quality } \\
\text { management process }\end{array}$ & $74.07 \%$ & $\begin{array}{l}80 \\
8 \\
8\end{array}$ & $\stackrel{\circ}{\infty}$ & 点 \\
\hline 9 & \multirow{2}{*}{$\begin{array}{l}\text { "Changing of } \\
\text { Attitude" }\end{array}$} & $\begin{array}{l}\text { Strong inclination to modify } \\
\text { existing work procedures to adapt } \\
\text { to the wants of quality system }\end{array}$ & $74.07 \%$ & 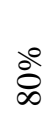 & 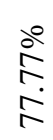 & $\begin{array}{l}\stackrel{8}{0} \\
\text { గn } \\
\text { రి }\end{array}$ \\
\hline 10 & & $\begin{array}{l}\text { An organizational culture must be } \\
\text { maintained that stresses on } \\
\text { construction works quality }\end{array}$ & $100 \%$ & 总 & $\stackrel{8}{8}$ & $\stackrel{8}{8}$ \\
\hline
\end{tabular}




\begin{tabular}{|c|c|c|c|c|c|c|}
\hline 11 & & $\begin{array}{l}\text { Allot adequate human resources } \\
\text { for quality management }\end{array}$ & $48.14 \%$ & 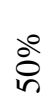 & $\stackrel{\substack{0 \\
+}}{+}$ & i̊ \\
\hline 12 & Resources" & $\begin{array}{l}\text { Allot adequate financial resources } \\
\text { for quality management }\end{array}$ & $33.33 \%$ & b̊ & $\stackrel{\stackrel{े}{m}}{\stackrel{m}{m}}$ & $\begin{array}{l}80 \\
\stackrel{0}{n} \\
\hat{n}\end{array}$ \\
\hline 13 & "Empowerment" & $\begin{array}{l}\text { Managers and supervisors should } \\
\text { authorize employees }\end{array}$ & $77.77 \%$ & @̊ & 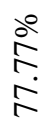 & $\begin{array}{l}80 \\
0 \\
n \\
\infty\end{array}$ \\
\hline 14 & "Leadership" & Maintain helpful leadership style & $100 \%$ & 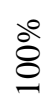 & $\stackrel{8}{8}$ & $\stackrel{8}{8}$ \\
\hline 15 & "Training" & Provide training for employees & $77.77 \%$ & ठి & $\frac{\stackrel{2}{R}}{\stackrel{2}{i}}$ & $\stackrel{80}{n}$ \\
\hline
\end{tabular}

Further, Tables No. $4 \& 5$ has been shown on top management obligation on quality management execution according to two mentioned strata of building and road projects. These are further divided including the score of clients, consultants and contractors of building and road projects respectively. From these tables it is specified that each item for all the formulates were evaluated on either "agreed" or "strongly agreed" scale. The result reveals that top management of the construction corporations is dedicated to quality management with respect to all mentioned factors except the factors of time, cost and resource allocation which needs more focus. The time is indirectly related to cost. Any interruption in project would cause financial liability (Irfan, Thaheem, Gabriel, Malik, \& Nasir, 2019). In the construction industry of Pakistan whether they are clients, consultants or contractors, consideration has always been given to only cost and time over quality. The importance of quality still needs to be recognized. The overall percentage of respondents who "agreed" and "strongly agreed" to all the 15 statements of questionnaire is shown in Figure 2.

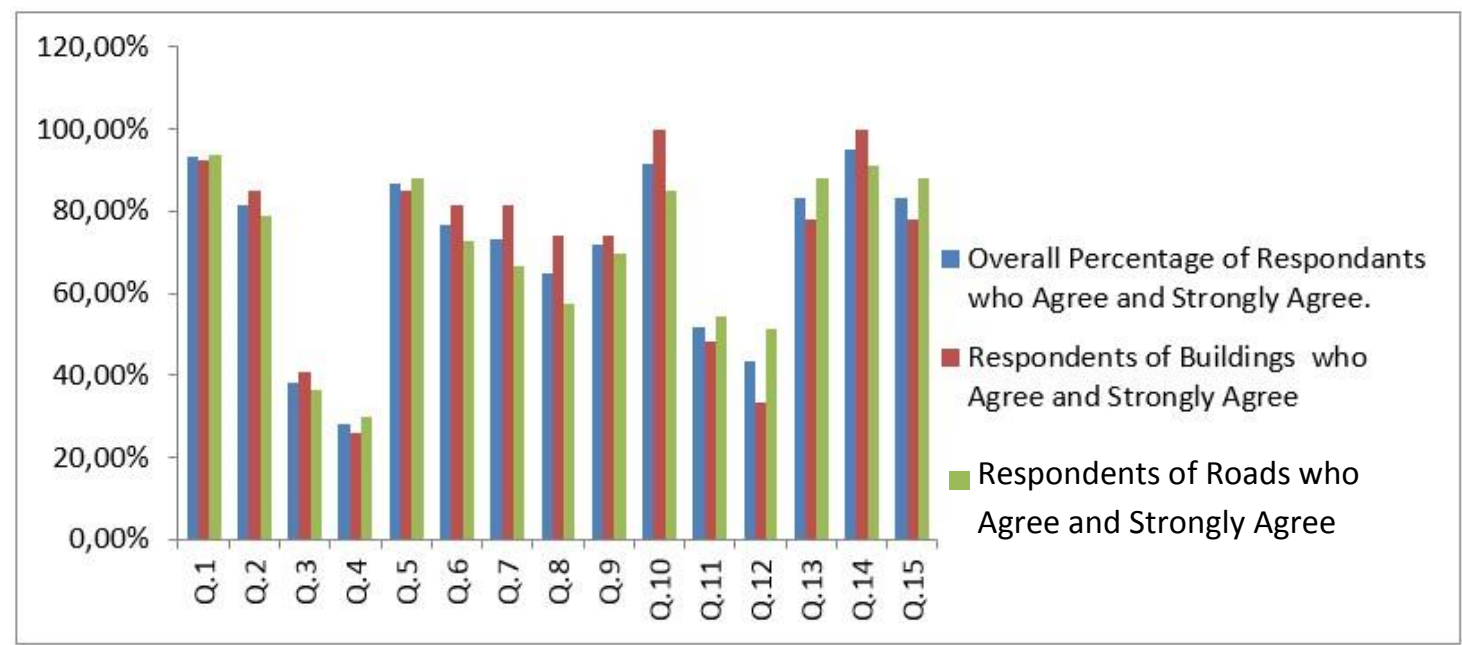

Figure 2: Percentage of Overall, Buildings and Roads Respondents who "Agree" and "Strongly agree" to the 15 Statements 
Table 5: Respondents from roads projects

\begin{tabular}{|c|c|c|c|c|c|c|}
\hline \multicolumn{7}{|c|}{ ROAD PROJECTS } \\
\hline $\begin{array}{l}\stackrel{2}{z} \\
\dot{\bar{s}}\end{array}$ & 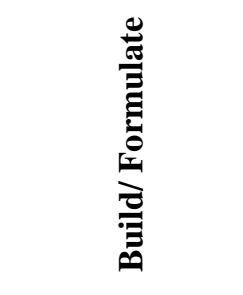 & & 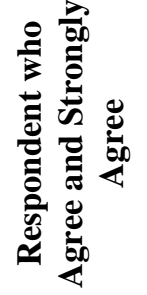 & 莺 & 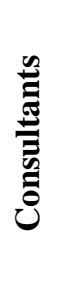 & 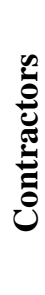 \\
\hline 1 & \multirow{2}{*}{$\begin{array}{l}\text { "Goals for } \\
\text { Quality" }\end{array}$} & $\begin{array}{l}\text { Pinpoint goals of quality for } \\
\text { project management to } \\
\text { accomplish }\end{array}$ & 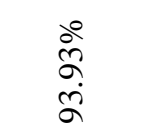 & $\begin{array}{l}\stackrel{\infty}{0} \\
\stackrel{\infty}{\infty} \\
\infty\end{array}$ & $\stackrel{8}{8}$ & $\stackrel{8}{\varnothing}$ \\
\hline 2 & & $\begin{array}{l}\text { Guarantee that quality goals } \\
\text { of project are known to } \\
\text { every participant of project } \\
\text { management team }\end{array}$ & $\begin{array}{l}\frac{\infty}{\infty} \\
\stackrel{\infty}{\infty} \\
\infty\end{array}$ & 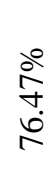 & $\begin{array}{l}\stackrel{0}{0} \\
\stackrel{n}{\infty} \\
\infty\end{array}$ & $\stackrel{\circ}{i}$ \\
\hline 3 & \multirow{2}{*}{ "Priority" } & $\begin{array}{l}\text { Consider quality as being } \\
\text { more imperative than cost. }\end{array}$ & $\begin{array}{l}\stackrel{0}{0} \\
\stackrel{0}{0} \\
i \\
i\end{array}$ & $\frac{\text { bo }}{\dot{\gamma}}$ & $\begin{array}{l}\stackrel{\circ}{0} \\
\stackrel{n}{0} \\
\text { b }\end{array}$ & $\stackrel{\circ}{\stackrel{2}{a}}$ \\
\hline 4 & & $\begin{array}{l}\text { Consider quality as being } \\
\text { more imperative than time. }\end{array}$ & $\begin{array}{l}\stackrel{\circ}{0} \\
\stackrel{0}{0} \\
\dot{m}\end{array}$ & 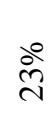 & $\begin{array}{l}\stackrel{0}{0} \\
\vdots \\
i \\
\infty\end{array}$ & $\begin{array}{l}\stackrel{0}{0} \\
\vdots \\
\text { ñ } \\
n\end{array}$ \\
\hline 5 & \multirow{2}{*}{ "Efforts" } & $\begin{array}{l}\text { Make sure that constant } \\
\text { efforts are made in } \\
\text { enhancing the quality of } \\
\text { construction works }\end{array}$ & $\begin{array}{l}\frac{\circ}{\infty} \\
\stackrel{\infty}{\infty} \\
\infty\end{array}$ & 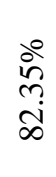 & छ̊ & 离 \\
\hline 6 & & $\begin{array}{l}\text { Continuously source for new } \\
\text { concepts to improve } \\
\text { construction work quality }\end{array}$ & $\stackrel{\stackrel{\leftrightarrow}{N}}{\stackrel{i}{i}}$ & $\begin{array}{l}\stackrel{0}{i} \\
\infty \\
\infty \\
\infty \\
i\end{array}$ & $\stackrel{8}{\varrho}$ & $\stackrel{\circ}{i}$ \\
\hline 7 & \multirow{2}{*}{ "Involvement" } & $\begin{array}{l}\text { Implicate regularly in the } \\
\text { quality management process }\end{array}$ & $\begin{array}{l}\frac{\circ}{6} \\
\stackrel{0}{0}\end{array}$ & $\begin{array}{l}\stackrel{0}{0} \\
\infty \\
\infty \\
i \\
i n\end{array}$ & 욤 & $\stackrel{\circ}{i}$ \\
\hline 8 & & $\begin{array}{l}\text { Individually involved in the } \\
\text { quality management process }\end{array}$ & $\begin{array}{l}\frac{0}{N} \\
n \\
i n\end{array}$ & $\begin{array}{l}\stackrel{8}{a} \\
\text { ì } \\
\text { in }\end{array}$ & $\stackrel{\circ}{i}$ & 官 \\
\hline 9 & $\begin{array}{l}\text { "Changing of } \\
\text { Attitude" }\end{array}$ & $\begin{array}{l}\text { Strong inclination to modify } \\
\text { existing work procedures to } \\
\text { adapt to the wants of quality } \\
\text { system }\end{array}$ & $\begin{array}{l}\stackrel{\circ}{0} \\
\text { gे }\end{array}$ & $\begin{array}{l}\stackrel{0}{\sim} \\
\infty \\
\infty \\
\infty \\
\infty\end{array}$ & $\begin{array}{l}\stackrel{8}{0} \\
\stackrel{\infty}{\infty} \\
\infty\end{array}$ & $\stackrel{\circ}{i}$ \\
\hline
\end{tabular}




\begin{tabular}{|c|c|c|c|c|c|c|}
\hline 10 & & $\begin{array}{l}\text { An organizational culture } \\
\text { must be maintained that } \\
\text { stresses on construction } \\
\text { works quality }\end{array}$ & $\begin{array}{l}\circ \\
\dot{+} \\
\infty \\
\dot{+}\end{array}$ & $\begin{array}{l}\stackrel{0}{i} \\
\substack{\infty \\
\infty} \\
\infty\end{array}$ & $\begin{array}{l}80 \\
\substack{n \\
\infty \\
\infty}\end{array}$ & $\begin{array}{l}80 \\
\substack{n \\
\infty} \\
\infty\end{array}$ \\
\hline 11 & \multirow{2}{*}{$\begin{array}{l}\text { "Allocate } \\
\text { Resources" }\end{array}$} & $\begin{array}{l}\text { Allot adequate human } \\
\text { resources for quality } \\
\text { management }\end{array}$ & 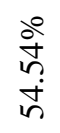 & $\begin{array}{l}\stackrel{0}{0} \\
\infty \\
\infty \\
\infty \\
i n\end{array}$ & $\stackrel{\circ}{i}$ & $\begin{array}{l}\stackrel{0}{a} \\
\stackrel{a}{v}\end{array}$ \\
\hline 12 & & $\begin{array}{l}\text { Allot adequate financial } \\
\text { resources for quality } \\
\text { management }\end{array}$ & $\frac{b}{n}$ & 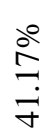 & $\begin{array}{l}\delta_{0}^{0} \\
\vdots \\
\infty \\
\infty\end{array}$ & $\begin{array}{l}\dot{8} \\
\stackrel{0}{n} \\
\text { nn }\end{array}$ \\
\hline 13 & "Empowerment" & $\begin{array}{l}\text { Managers and supervisors } \\
\text { should authorize employees }\end{array}$ & $\begin{array}{l}\frac{0}{\infty} \\
\infty \\
\infty \\
\infty\end{array}$ & $\begin{array}{l}\stackrel{8}{0} \\
\substack{\infty \\
\infty \\
\infty}\end{array}$ & $\begin{array}{l}80 \\
\substack{\infty \\
\infty}\end{array}$ & $\stackrel{8}{8}$ \\
\hline 14 & "Leadership" & $\begin{array}{c}\text { Maintain helpful leadership } \\
\text { style }\end{array}$ & $\begin{array}{l}8 \\
\text { ̊̊ } \\
8\end{array}$ & $\begin{array}{l}\stackrel{0}{0} \\
\text { ते } \\
\infty \\
\infty\end{array}$ & $\stackrel{8}{8}$ & $\begin{array}{l}\delta_{0}^{0} \\
\vdots \\
\infty \\
\infty\end{array}$ \\
\hline 15 & "Training" & $\begin{array}{l}\text { Provide training for } \\
\text { employees }\end{array}$ & $\begin{array}{l}\frac{0}{\infty} \\
\infty \\
\infty \\
\infty\end{array}$ & 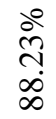 & $\stackrel{\stackrel{0}{n}}{n}$ & $\stackrel{8}{8}$ \\
\hline
\end{tabular}

\subsection{Spearman's rank correlation coefficient}

Spearman's rank correlation coefficient is used to highlight whether there is the consensus or difference of opinion among the groups of respondents. Table 6 shows the results of Spearman's coefficient. Spearman's coefficient highlights that there is a strong consensus between three groups of respondents i.e. contractors, clients, and consultants on the constructs and are of the view that top management of Pakistani construction organizations are normally committed to quality management engagement from the perspective of quality goals, efforts, involvement, attitude to change, empowerment of employees, leadership style and trainings.

Table 6: Spearman rank correlation coefficient

\begin{tabular}{|l|c|c|}
\hline \multicolumn{1}{|c|}{ Respondent groups } & $\begin{array}{c}\text { Spearman Rank Correlation } \\
\text { Coefficient }\end{array}$ & Significance Level \\
\hline Contractor-Consultant & 0.781 & 0.000 \\
\hline Contractor-Client & 0.801 & 0.000 \\
\hline Consultant-Client & 0.812 & 0.000 \\
\hline
\end{tabular}

\section{CONCLUSION AND RECOMMENDATIONS}

The idea of application of quality is somewhat new in Pakistan's construction industry. Without the implementation of quality in the construction, projects undertaken in Pakistan can end up being a complete disaster (Farooqui, Ahmed, \& Lodi, 2008). From the results of this study, it can be inferred that top management of Pakistani construction corporations are normally dedicated to quality management enactment from the viewpoints of quality goals, efforts, involvement, attitude to change, empowerment of employees, leadership style and trainings. However, the situation is very alarming regarding other formulates/builds. Majority of projects in Pakistan suffer due to poor quality (Sohu, Ullah, Jhatial, Jaffar, \& Lakhiar, 2018). Firstly, 
top management is reluctant to prefer quality over time and cost. Whether it is client, consultant or contractor everyone is not willing to sacrifice time and cost for the sake of quality. Secondly, top management is not willing for the provision of additional resources for the enactment of quality.

The findings of this research are a grave concern as they give an explanation as to why quality hitches occur in the Pakistani construction industry. It is the need of hour that the top management of the construction organizations should change their thinking and give more preference to quality in project management to end the enigma of poor project performance in the perspective of quality management (Rashed, 2015). The current study will act as a source of guidance for key stakeholders and top management in implementing the quality management practices.

Current study has relied on the information from one geographical region (Pakistan). Future studies can investigate this downside in alternative countries or regions and will additionally account for the variations between countries (i.e. taking consideration of variations of environmental awareness during a given country or variations of stringency of native legislation). All future work would further contribute to the understanding the role of top management towards quality management in the construction industry.

\section{REFERENCES}

Abdul-Rahman, H. (1996). Some observations on the management of quality among construction professionals in the UK. Construction Management and Economics. 14(6), pp. 485-495. https://doi.org/10.1080/01446199637319 7

Ahire, S. L., \& O'shaughnessy, K. C. (1998). The role of top management commitment in quality management: an empirical analysis of the auto parts industry. International Journal of Quality Science. 3(1), pp. 5-37.

Arditi, D., \& Gunaydin, H. M. (1997). Total quality management in the construction process. International Journal of Project
Management. 15(4), pp. 235-243. https://doi.org/10.1016/S02637863(96)00076-2

Ashford, J. L. (2002). The management of quality in construction.

Asim, M., uz Zaman, S., \& Zarif, T. (2013). Implementation of Total Quality Management in Construction Industry: A Pakistan Perspective. Journal of Management and Social Sciences. 9(1), pp. 24-39.

Barrett, P. (2000). Systems and relationships for construction quality. International Journal of Quality and Reliability Management. 17(4), pp. 377-392. https://doi.org/10.1108/02656710010298 409

Biggar, J. L. (1990). Total quality management in construction. Transactions of the American Association of Cost Engineers.

Chan, A., \& Tam, C. M. (2000). Factors affecting the quality of building projects in Hong Kong. International Journal of Quality \& Reliability Management. 17(45), pp. 423-442.

Chan, A. M. Y., Chu, F. W. W., \& Yuen, C. K. (2000). A Successful TQM Project in China. International Journal of Commerce \& Management. 10(2), pp. 75-90.

Chin, K. S., \& Choi, T. W. (2003). Construction in Hong Kong: Success Factors for ISO 9000 Implementation. Journal of Construction Engineering and Management, pp. 599-609.

Chin, K. S., Tummala, V. M. R., \& Chan, K. M. (2003). Quality management practices in Hong Kong industries: A comparison between electronics and toys manufacturing industries. International Journal of Quality \& Reliability Management. 20(9), pp. 1051-1083.

Cho, J. H. (2017). An empirical study on top management's leadership in construction quality management activities and construction quality management performance. Journal of the Korean Society for Quality Management. 45(3), pp. 403-426.

Crosby, P. (1984). Quality without Tears: The Art of Hassle-Free Management.

Dadzie, P. S. (2004). Quality Management 
Initiatives in Balme Library: Possibilities, Challenges and Constraints for Top Management Commitment. Library Management. 25(1/2), pp. 56-61.

Elghamrawy, T., \& Shibayama, T. (2008). Total quality management implementation in the Egyptian construction industry. Journal of Management in Engineering. 24(3), pp. 156-161.

Farooqui, R. U., Ahmed, S. M., \& Lodi, S. H. (2008). Assessment of Pakistani construction industry-current performance and the way forward. Journal for the Advancement of Performance Information and Value. 1(1), pp. 51-72. http://citeseerx.ist.psu.edu/viewdoc/dow nload?doi=10.1.1.852.352\&rep=rep1\&ty pe $=$ pdf

Garcia-Bernal, J., \& Garcia-Casarejos, N. (2020). Determinants in the adoption of total quality management (TQM) in the construction sector: a management perspective. Journal of Construction. 15(2), pp. 28-36.

Goetsch, D. L. (1997). Introduction to total quality: Quality management for production, processing, and services. Prentice Hall.

Goffin, K., \& Szwejczewski, M. (1996). Is management commitment to quality just “a given"? TQM Magazine. 8(2), pp. 2631.

https://doi.org/10.1108/09544789610114 821

Greasley, K., Bryman, A., Dainty, A., Price, A., Soetanto, R., \& King, N. (2005). Employee perceptions of empowerment. Employee Relations.

Harris, F., \& McCaffer, R. (2001). Modern construction management (5th ed.). Oxford: Blackwell Science Ltd.

Haupt, T. C., \& Whiteman, D. E. (2004). Inhibiting Factors of Implementing Total Quality Management on Construction Sites. The TQM Magazine. 16(3), pp. 166-173.

Irfan, M., Malik, M. S. A., \& Kaka Khel, S. S. U. H. (2020). Effect of factors of organizational structure influencing nonphysical waste in road projects of developing countries. Engineering, Construction and Architectural Management. https://doi.org/10.1108/ECAM-06-20190327

Irfan, M., Thaheem, M. J., Gabriel, H. F., Malik, M. S. A., \& Nasir, A. R. (2019). Effect of stakeholder's conflicts on project constraints: a tale of the construction industry. International Journal of Conflict Management. 30(4), pp. 538-565. https://doi.org/10.1108/IJCMA-04-20190074

Jaafari, A. (2000). Construction Business Competitiveness and Global Benchmarking. Journal of Management in Engineering. pp. 43-53.

Kuo, T. H., \& Kuo, Y. L. (2010). The effect of corporate culture and total quality management on construction project performance in Taiwan. Total Quality Management. 21(6), pp. 617-632.

Landin, A. (2000). Impact of quality management in the Swedish construction process.

Low, S. P., \& Omar, H. F. (1997). The effective maintenance of quality management systems in the construction industry. International Journal of Quality \& Reliability Management.

Memon, N. A., Khatri, K. L., \& Memon, A. B. (2013). TQM in Construction and Manufacturing Companies of Pakistan: A Case Study. Mehran University Research Journal of Engineering \& Technology. 32(2), pp. 261-268.

Oxford Dictionary. (2001). The New Oxford Dictionary of English. Oxford: Oxford University Press.

Pheng, L. S., \& Teo, J. A. (2004). Implementing Total Quality Management in Construction Firms. Journal of Management in Engineering. 20(1), pp. 8-15.

Rashed, A. (2015). Implementing Quality Management in Construction Projects. Proceedings of the 2015 International Conference on Industrial Engineering and Operations Management, pp. 3-5.

Rodgers, R., Hunter, J. E., \& Rogers, D. L. (1993). Influence of top management on 
management program success. Journal of Applied Psychology. 78(1), pp. 151-155.

Rosenfeld, Y. (2009). Cost of quality versus cost of non-quality in construction: The crucial balance. Construction Management and Economics. 27(2), pp. 107-117. https://doi.org/10.1080/01446190802651 744

Russel, R. S., \& Taylor, B. (2006). Operations Management: Quality and Competitiveness in a Global Environment (5th ed.). John Wiley \& Sons, Inc.

Savolainen, T. (2000). Leadership strategies for gaining business excellence through total quality management: a Finnish case study. Total Quality Management. 11(2), pp. 211-226.

Sohu, S., Ullah, K., Jhatial, A. A., Jaffar, M., \& Lakhiar, M. T. (2018). Factors adversely affecting quality in highway projects of Pakistan. International Journal of Advanced and Applied Sciences. 5(10), pp. 62-66.

Sullivan, K. T. (2011). Quality management programs in the construction industry:
Best value compared with other methodologies. Journal of Management in Engineering. 27(4), pp. 210-219. https://doi.org/10.1061/(ASCE)ME.1943 $-5479.0000054$

Tavakol, M., \& Dennick, R. (2011). Making sense of Cronbach's alpha. International Journal of Medical Education. 2, pp. 5355.

Taylor, W. A., \& Wright, G. H. (2003). The Impact of Senior Managers' Commitment on The Success of TQM Programmes - An Empirical Study. International Journal of Manpower. 24(5), pp. 535-550.

Thevnin, C. (2004). Effective Management Commitment Enhances Six Sigma Success. Handbook of Business Strategy, pp. 195-200.

Ugboro, I. O., \& Obeng, K. (2000). Top management leadership, employee empowerment, job satisfaction, and customer satisfaction in TQM organizations: an empirical study. Journal of Quality Management. 5(2), pp. 247-272. 